\title{
The Function of Pantun in the Art Performace of Batang Hari Sembilan Solo Guitar during Sedekah Bumi Ceremony Held in Batu Urip Hamlet, South Sumatera
}

\author{
Imelda Tri Andari, Suharto Suharto \\ Universitas Negeri Semarang, Indonesia
}

Submitted: August 13, 2020. Revised: September 9, 2020. Accepted: November 4, 2020

\begin{abstract}
This study aims to describe the form and function of the solo guitar performance of Batang Hari Sembilan in Batu Urip hamlet, Batu Urip Taba village, Lubuklinggau city, South Sumatra. This study used a qualitative de-scriptive approach. Data collection techniques using observation, interviews, and documentation. The collected data were then analyzed using analytical and interactive techniques with data reduction, data presentation, and conclusion drawing. Based on the discussion that has been done, this study found that the Single Batang Hari Sembilan Guitar is a rhythm of guitar strings containing rhymes. Pantun is an identity and plays a very important role in the life of the community. The function of the pantun in the solo guitar performance of Batang Hari Sembilan was originally used as a communication function. Currently, this art performance has developed, namely as a ritual function, a function of preserving culture, a function of entertainment, a function of cultural continuity, a function of means of communication, and a function of emotional expression.
\end{abstract}

Keywords: pantun; solo guitar; sedekah bumi

How to Cite: Andari, I. T., \& Suharto, S. (2020). The Function of Pantun in the Art Performace of Batang Hari Sembilan Solo Guitar during Sedekah Bumi Ceremony Held in Batu Urip Hamlet, South Sumatera. Harmonia: Journal of Arts Research And Education, 20(2), 195-204

\section{INTRODUCTION}

Culture is a behavior that has become ritual, symbol, icon, and others and eventually has a structural function in social life (Gill 2013). Malay culture, as one of the various cultures, should first learn what the meaning of culture is. Malay culture is anything resulted from the Malay humans' creation, feeling, and inten-tion (Andriani, 2012). In Malay culture, expressions have important roles since these literary forms usually are full of and rich with advice and learning values.

According to (Akmal, 2015), Malay people's expertise in arranging expressions has been long admired by many people, such as gentle character, high morality and politeness, and other true values. Those can be commonly listened from their utterances. Malay literary culture is not separable from gurindam, pantun and syair. Thus, it is not surprising if each Malay wedding ceremony ritual stage, pantun and syair are frequently used. According to Sayekti (2009), Malay classic literature's typical characteristics are seen in both intrinsic and extrinsic elements and shown in the writers' appearance who never attach their names in their writing compositions.

\footnotetext{
Corresponding author:

E-mail: suharto@mail.unnes.ac.id
} 
They considered that literary work did not belong to an individual writer but mutually belongs to society.

Tenas Effendy expressed those in risalah journal (Akmal 2015), stating that Malay cultural practitioners illustrated Malay people's life without pantun is just like a crowded city yet felt quiet. Thus, Malay people cannot be separated from pantun as it is a part of Malay people's souls. According to Erwina (2011), pantun is one old and extensive Malay poem known in many languages throughout Indonesia.

The most general characteristic is that pantun consists of four lines (when written), also known as a stanza in the theory of literature-having each line/stanza pattern of $a-b-a-b$ or $a-a-a-a$.

Pantun for Malay people has been used in all life aspects, including pantunbased traditional songs. The most frequently appearing Malay pantun couplets are the plant, fruit, region, river, animal, natural formation (mountain, hill, river, cliff), and daily activity (Firmansyah, 2015).

Artists use natural phenomena and their regional traditions as the pantun couplet materials. The beauty of a song is determined by the related elements between song melodies and lyrics. Lyric is a part of the song giving new dimensions in music composition; making language, such as pantun and poem, is more beautiful to listen (Suharto \& Subroto, 2014).

Music's function is an essential issue in ethnomusicology since dealing with music's meaning, yet not related to the facts that deal with music. However, ethnomusicology always tries to collect facts related to music (Merriam, 1964). Culture (in its society) is its efficacy in fulfilling the existing needs or in achieving certain goals. However, we recently try to find music's function in general, not only in a certain community. The functions of music, as stated by (Merriam, 1964), include emotional disclosure, esthetical appreciation, entertainment, communication, Symbolic Representation, physical reaction, social norm, social institution legalization and religious ceremony, cultural sustainability, and community integration.

According to (Soedarsono, 1995) some art performances also have the function of a ritual. The ritual function of the art performance in Indonesia, which has been developing in society, still refers to the rules and regulations of life referring to agricultural and cultural values. The society that believes in certain religions with religious activities greatly involves art performances. One traditional art still existing in Indonesia is the art performance of $\mathrm{Ba}$ tang Hari Sembilan Solo Guitar.

The art performance of Batang Hari Sembilan Solo Guitar has been growing and developing in the areas of South Sumatera said (Firmansyah 2015). In each sedekah bumi ceremony, the hamlet people perform an art belonging to their community to realize and express gratitude. The art performance of Batang Hari Sembilan Solo Guitar is one form of the traditional art of which lyrics are in the form of pantun sung and accompanied by a musical instrument of acoustic guitar.

This art in the society serves as entertainment, economical vehicle, suggesting media, and the requirement for holding sedekah bumi. As one medium to express the creativities of art workers and society, this can be seen when the society together watches the art performance of Batang Hari Sembilan Solo Guitar and interacts with each other after listening to the sung pantun lyrics.

After noticing the role of pantun in the art performance of Batang Hari Sembilan Solo Guitar in the social life in Batu Urip Hamlet, this article is written to disclose the functions of pantun in that art performance and describe the role of pantun as the true self-identity of Malay people and the role of pantun in Malay people's life in Batu Urip Hamlet. This is one of the interesting reasons to research why Malay people cannot be separable from pantun and pantun has become part of the soul.

\section{METHOD}

The method employed in this rese- 
arch was the qualitative method with the descriptive approach, which means that this research was conducted by giving a description or picture of data pursuant to the fact of objects studied. The research's form is qualitative. The research procedure was one which produces descriptive data in the form of meaning and functions of pantun in the Batang Hari Sembilan Solo Guitar art and to be followed up by implementing learning pantun at school.

The research's source of data was pantuns read by $\mathrm{Hj}$. Saliyam when performing the Batang Hari Sembilan Solo Guitar art in sedekah bumi activities. The data were collected through interviews and documentation techniques. The interview technique was conducted with the informants, namely $\mathrm{Hj}$. Saliyam and Rohana. Further data collection was conducted using documentation study technique on the video of Batang Hari Sembilan Solo Guitar art performance obtained by the researcher from Silampari TV and from the Informants.

The documentation study technique is one data collection technique using the document as the source of research data, private documents, and official documents. The purpose of using the documentation study technique is to conclude the data with the following steps: 1) watching a video of Batang Hari Sembilan Solo Guitar art performance 2) writing the pantuns listened from the video; 3 ) reading the collection of pantuns intensively; 4) identifying the data pursuant to the research problem, namely meaning and functions of pantun; 5) classifying the data into meaning and functions of pantun; and 6) noting the data of pantuns which are pursuant to the research problem.

Based on the data analysis technique, the data were analyzed with the following steps: 1) analyzing and interpreting the meaning of pantun; 2) analyzing and interpreting the function of pantun; 3) discussing the research result together with an academic adviser; and 4) concluding the data analysis result of the research on the Function of Pantun in Batang Hari Sem- bilan Solo Guitar Art Performance in Sedekah Bumi Activities in Batu Urip Hamlet, Batu Urip Taba Village, Lubuklingau City, South Sumatera.

\section{RESULT AND DISCUSSION}

\section{Customary Culture in Batu Urip Hamlet}

The culture of the people of Lubuklinggau City is identical to the Malay community's culture because this community is a Malay ethnic. This community is the same culture as ethnic Malays in various regions, such as in Riau, Jambi, Lampung, South Sumatra, Bangka Belitung, Kalimantan, and others.

The same also applies to Malay people in the Peninsulas of Malaysia, Sabah, Serawak, Pattani, Cambodia, Sri Lanka, Madagascar, etc. In addition, as stated by (Erwina, 2011) the custom (adat) of Malay ethnic is divided into four, namely adat yang sebenar adat, adat yang di adatkan, adat yang teradat, and adat istiadat.

The customary activity which is still performed by the people of Urip hamlet is the Sedekah Bumi activity. The Sedekah Bumi activity is performed annually in Batu Urip hamlet, Batu Urip Taba Village. The customary ceremonial activity of sedekah bumi is believed by the people Batu Urip Hamlet to summon the spirits that have passed away so that the people of Batu Urip hamlet will be given safety express their gratitude. It is believed by the people of Batu Urip Taba to repel misfortune.

The belief of Batu Urip hamlet people in sedekah bumi activity has existed from their ancestral period. This activity is the cultural legacy of their ancestor that causes syncretism. Syncretism is a process of fusion between some religious concepts or schools or beliefs.

As stated by Geertz (1964), the majority of the Javanese people's belief system may be divided into three categories, namely abangan, santri, and priyayi. Geertz states that abangan represents the emphasis on the animistic aspect of Javanese syncretism in its entirety and is widely related to the farmer element, the santri population 
represents the emphasis on Islamic aspects of syncretism and is generally related to the trade element, and priyayi emphasizes Hindu aspects and is related to a bureaucratic element.

Sedekah Bumi or Sedekah Rame or lepung dusun is a customary ceremony performed hereditarily by the people of South Sumatera, particularly the people of Batu Urip, aiming at repelling misfortune and inviting fortune (sustenance). In addition, Sedekah Bumi also serves to keep the hamlet tradition so that it will not get extinct and will be passed down to the next generation. Sedekah bumi may also strengthen the connection between the people of Batu Urip Hamlet.

Sedekah rame is usually performed at least biannually but may also be performed when there is a disaster or a good event such as constructing a bridge, mosques, etc. Sedekah Bumi is the tradition aiming at surrendering to the creator, expressing gratitude for any fortune and grace bestowed. Sedekah Bumi has been performed from their ancestral period and is passed down hereditarily.

A Sedekah Bumi or Sedekah Rame ceremony starts by performing the arts of Batu Urip hamlet such as Sekapur Sirih Dance and Batang Hari Sembilan Solo Guitar. Sekapur Sirih Dance is one of the existing cultures often performed in the life of the people of Batu Urip Taba Village. Sekapur Sirih dance is a dance marking that a sedekah bumi or sedekah rame ceremonial event will soon start.

Batang Hari Sembilan Solo Guitar Art is a traditional art which is still developing in Batu Urip Hamlet, Batu Urip Taba Village, East Lubuklinggau I Subdistrict, Lubuklinggau City, South Sumatera Province. The people serve as the actor, creator, and organizer of the art. Generally, Batang Hari Sembilan Solo Guitar art is held to gather the people and as private entertainment for its actor. This art is usually performed in sedekah bumi, wedding reception, circumcision events, etc. This art is also always performed annually in sedekah bumi/ sedekah rami event. In Batang Hari Sembilan Solo
Guitar art performance, there is a song sung along with it. The song is in the form of pantun, and pantun song of Gitar Tunggal Batang Hari Sembilan sung in this art has its function. Although there are various songs of Batang Hari Sembilan Solo Guitar art, the music played is the same (Interview with Saliyam, 28 December 2018).

The characteristic of Malay pantun is that the first couplet takes words from the environment. This is also said by (Ritawati 2018, Firmansyah 2015) that the words are often emerging in the first couplet of Malay pantun are names of plant, fruit, region, animal, natural formation such as mountain, hill, river, and hill. Below is an example of pantun using natural name.

Dakya dayang jeribat

Tarak tebekur gunung bukuk

Menjelma jadi malaikat empat

Satu malaikat ngajum tepuk

As we may see in the second line, "Tarak tebekur gunung bukuk," the first couplet of the pantun above uses the word "gunung". Gunung (mountain) is the name of a natural formation. According to Saliyam (interview on 28 December 2019), the characteristics of pantun of Malay culture, to be exact in Batu Urip hamlet, tend to frequently use names of the surrounding environment, such as region names, culture, and nature since it is deemed to respect them.

As stated by (Shafii, 2010) that pantun and natural elements actually cannot be separated since the concerned natural element refers to flora and fauna. People who live in the village, by the river, near the forest, often use natural elements since they live with nature and the scope of a natural element.

In Batang Hari Sembilan Solo Guitar Art, there are some kinds of pantun songs, but the music used is the same, and there is no standard sequence. The musical instrument used is only Hitar (Guitar). According to Kadalik, pantun has become a tradition and habit for the people of Batu Urip hamlet. The people of Batu Urip hamlet has from their ancestral period until 
now consistently used pantun everywhere. To them, talking by exchanging pantun will make the atmosphere different. A tense atmosphere will become relaxed.

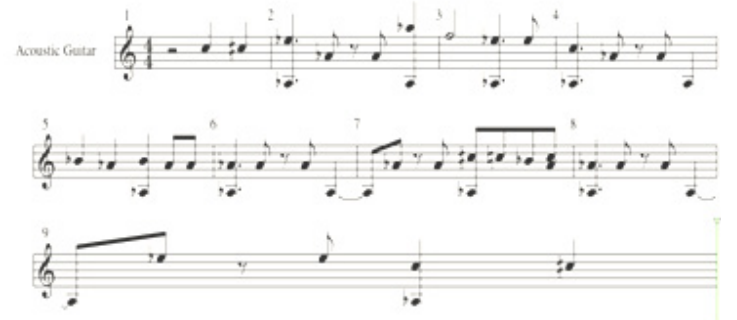

Figure 1. Pattern of accompanying Batang Hari Sembilan Solo Guitar
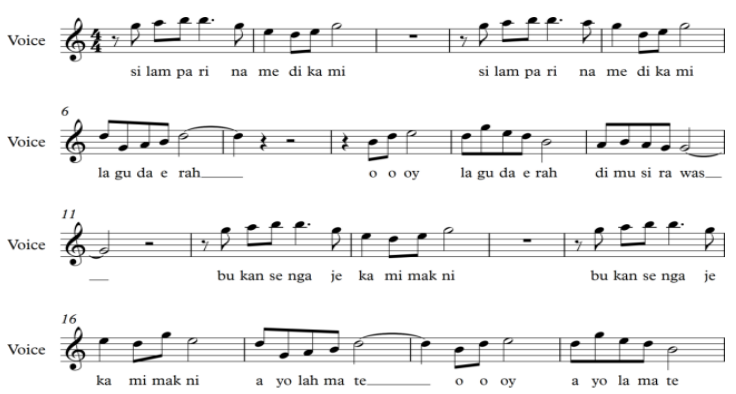

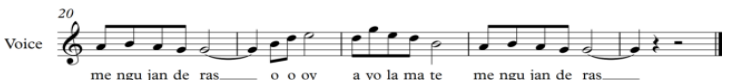

Figure 2. Musical Score of Silampari Song of Batang Hari Sembilan Solo Guitar Art

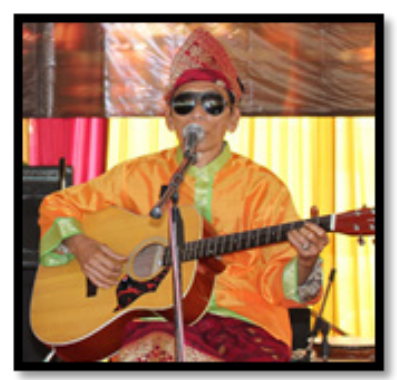

Figure 3. Batang Hari Sembilan Solo Guitar Player with Traditional Malay Dress

Batu Urip hamlet people cannot be separated from pantun in Batang Hari Sembilan Solo Guitar art, since if the people in Batu Urip hamlet do not recite pantun even only a day, they will feel hollow and something is missing (Interview, Kadalik, 04 December 2018). Thus what is stated by (Sayekti, 2009) is correct that Malay cultural literature cannot be separated from gurindam, pantun and poem. Thus it is not surprising that each stage of the ri- tual of Malay wedding ceremony is also loaded with the use of pantun and poem. Each poem and pantun reveals meaning in-depth, as reflected in berinai, berandam, mandi damai ceremonies, etc.

\section{The Function of Pantun in Batang Hari Sembilan Solo Guitar Art}

An art which grows in the society has some important functions to the people who preserve it. Art is one element of culture, occurring since humans initially want to satisfy their instinctive desire for beauty. Batang Hari Sembilan Solo Guitar art performance, for example, has a number of functions behind the pantun songs, which are closely related to fertility and safety.

The existence of Batang Hari Sembilan Solo Guitar art in Sedekah Bumi activity in Batu Urip hamlet is the medium to give advice, express the gratitude, trust, and belief of in Batu Urip hamlet through art. The lyrics of pantun sung in Batang Hari Sembilan Solo Guitar art have a number of Ritual function and Emotional expression function in Sedekah Bumi activity to the people in Batu Urip hamlet as follows:

\section{Ritual Function}

Since the beginning, it is stated that Batang Hari Sembilan Solo Guitar art is an art for ritual since the lyrics of pantun of the art song in the opening serves to summon ancestral spirits to attend the sedekah bumi ceremonial activity. This art performance is believed to have magical power. Batang Hari Sembilan Solo Guitar art performance in sedekah bumi activities in Batu Urip Hamlet has a number of ritual functions; that each time sedekah bumi activity is held, the sekapur sirih dance art and Batang Hari Sembilan Solo Guitar art must be performed since they are to open the activity in order to live. Batang Hari Sembilan Solo Guitar Art must be performed every time sedekah bumi activity is performed since, in this art, there are pantuns. The pantuns sung aims at opening the activity by summoning the one luhur through pantun sung (Interview Kosim, 2 January 2019). 
Likewise, as stated by Soedarsono (1993), many Ritual Functions of Art Performance according to the ritual function of art performance in Indonesia develop in the society whose life order still refers to agrarian cultural values, and the society with religion whose worship activities often involves art performance.

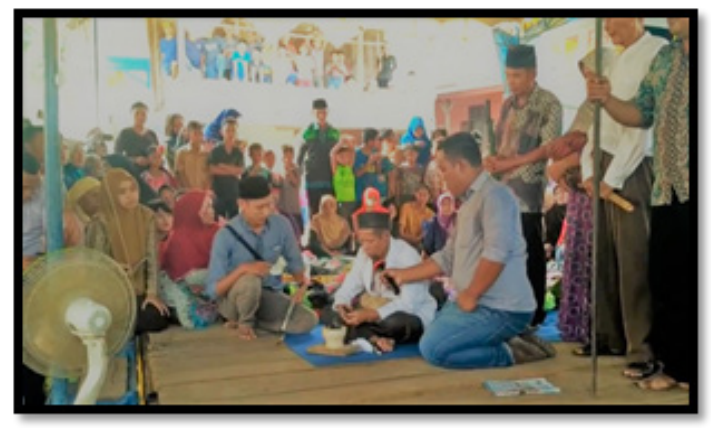

Figure 4. Mantra Recitation at SEdekah Bumi Ceremony

Byline, ritual art performance has distinctive features of needing chosen performance location which is often deemed sacred, needing chosen day and time which usually are also deemed sacred, needing selected players who are usually deemed holy or those who are spiritually cleansed, needing a set of offerings which are sometimes of various types and kinds, the objective is prioritized over aesthetic display, and need special clothing.

The lyrics of pantun sung in this activity are deemed to invite the ancestors to attend the activity. The people believe that their leluhur (ancestral) spirits join the joy in the sedekah bumi activity. This performance is also used to invite leluhur spirit to bless the people. In addition, pantun in this art is also a media to greet that the sedekah bumi has started. Below is an example of lyrics of pantun song to summon the ancestors:

Dakya dayang jeribat

Tarak tebekur gunung bukuk

Menjelma jadi malaikat empat

Satu malaikat ngajum tepuk

Due malaikat ngajum tari

Tige malaikat ngajum nyanyi

Empat malaikat ngajum sambai
Lime malaikat milu kebumi

Njede lebah oy beseng lebah

Lebah behahang gok buluh-buluh

Njede nyembaj oy beseng nyembah

Nyembah beharang jehai sepuluh

(Source: Saliyam, 28 December 2018)

The sedekah bumi customary ceremonial activity is believed by the people of Batu Urip Hamlet to summon spirits that have passed away ahead of the people in Batu Urip hamlet to give them safety, to express their gratitude, and to repel misfortune.

In the sedekah bumi customary ceremonial activity, the people float food on which spell has been recited by the customary leader. The food that is floated on Kelingi River is believed by the people of Batu Urip hamlet to be received by their ancestors. Thus the people of Batu Urip hamlet's wish for safety and avoidance of misfortune will be granted by them, and the floated food serves as their expression of gratitude and respect to the ancestors. This balances between religious and cultural beliefs. This belief has existed within Batu Urib hamlet's society since it has become their cultural tradition that is still performed until now.

According to Buana (interviewed 3 January 2019 ) in Islam, there is no worship or praying other than Allah SWT, as performed in Batu Urip hamlet to ask protection and express gratitude to the ancestors by reciting spells while burning frankincense. This belief has existed long in the life of the people in Batu Urip hamlet. This activity is a custom passed down by their ancestors. In the past, the religions of the people in this region were Hindu and Buddhism. However, these two religions did not survive long among common people, that only kings were allowed. Then, the common people might freely receive new elements. The history of the introduction of Islam into South Sumatera is that in the past, South Sumatera was a path passed by Islam propagators during Sriwijaya kingdom. 
The Batu Urip hamlet people's belief in sedekah bumi activity has existed from their ancestral period, and this activity is a cultural legacy from their ancestors, resulting in syncretism. Syncretism is a process of fusion between various religious concepts or beliefs, as stated by Geertz (1964) that the majority of Javanese people's belief system may be divided into three categories, namely abangan, santri, and priyayi.

Geertz states that abangan represents the emphasis on the animistic aspect of Javanese syncretism in its entirety and is widely related to the farmer element, the santri population represents the emphasis on Islamic aspects of syncretism and is generally related to the trade element, and priyayi emphasizes Hindu aspects and is related to bureaucratic element.

Meanwhile, according to Burhani (2017), Javanese people divide themselves into two categories: bangsa putihan and bangsa abangan (putih and merah). The former refers to a group that considers Islam as their way of life from inside to outside, while the latter refers to the majority of Javanese people who receive Islam as their formal religion, but other religions still guide their ideas and practices; thus syncretism occurs.

As stated by Eriswan (2011) that culture is the outcome of human cipta, rasa, and karsa, thus Islamic teaching is God's revelation. Although Some Malay people frankly do not perform Islamic practices, it is viewed only as a tradition that has no religious essence of religion, and if there is, it is only a belief level.

\section{Emotional Expression Function}

Each time Batang Hari Sembilan Solo Guitar art is performed, Batu Urip hamlet people immediately gather to watch it. In the sedekah bumi activity, after the artist's greeting and summoning of ancestral spirits, the pantun later contains gratitude, a sense of joy, and a reminder of past occurrence. The lyrics of pantun sung by the artist makes those who watch it get carried away and remember their relatives who have passed away and the past, making them shed tears.

Merriam (1964) stated that the emotional expression function is that the music has big power as a medium to express the singer's and players' feeling/emotion, which may raise listeners' feeling/emotion. The feeling expressed varies, including the feeling of admiring the world that God created, sad feeling, feeling of missing, proud feeling, calm feeling, etc. Emotion expression is sometimes needed for the soul's health since negative emotion expressed in daily life may be expressed in a song. Such an expression may reduce a person's feelings of frustration.

\section{Pantun with a Meaning of Happy Expres- sion}

In general, pantun has happy nuances, but in this art, it can have sad nuances. Pantun that usually means an expression of happiness in the art of Guitar Tunggal Batang Hari Sembilan has the meaning of a happy expression. It exists in pantun song. An example of pantun with a happy expression is in the following part of pantun

Benyak nia wang gelak majo

Majo gulai di mesak pindang

Benyak nia wang henyum honjo

Ulasa linjang bujang heberang

The meaning of the pantun above is that many girls in Batu Urip hamlet belinjangan (fall in love) with young men of other villages, and the girls are happy.

\section{Pantun with a Meaning of Sad Expres- sion}

Pantun with a meaning of sad expression exists in pantun song. An example of pantun with a sad expression is in the following part of pantun:

Panjang nia ikok ikan pari

Padek nia nijingok mate

Hedih nia nyolongla diri

Nak ngahape nak becerite

In the pantun above, the third and fourth lines "hedih nia nyolongla diri, nak ngahape nak becerite" means that it is quite 
sad to cry alone, whom to talk to. Thus, the pantun above is a sad expression.

\section{Pantun with a Meaning of Restless Ex- pression}

Pantun with a meaning of relentless expression in the Batanghari Sembilan Solo Guitar art also exists in the following lyric of pantun:

Umak-umak ayam ku luput

Ayam ku luput hakoe jerang

Umak-umak atiku kusut

Atiku kusut ku linjang suhang

The meaning of pantun above is an expression of a person who is still alone, as may be observed in the fourth line "Atiku kusut ku linjang suhang" which means that his heart gets confused since he is alone. The example above is a pantun to express relentless feeling. Thus this pantun of the Batang Hari Sembilan Solo Guitar art contains the emotional expression function.

According to (Erwina, 2011) Malay pantun is the identity of Malay people and the medium to express personal feeling to entertain oneself and an aesthetic presentation.

\section{Function of Medium of Communication in Social Life}

Batang Hari Sembilan Solo Guitar Art which is a traditional art in Batu Urip hamlet cannot be separated from the society's role as the one involved in its preservation, organization, and audience. As a culture society, it is appropriate that respect is kept to their ancestors' history and heritage, one of which is by organizing Batang Hari Sembilan Solo Guitar art performance in every sedekah bumi activity.

Batang Hari Sembilan Solo Guitar Art in sedekah bumi activities is an art to express their gratitude, thus it is expected that the people who perform the ritual of sedekah bumi activity attempt to communicate with "they who are invisible", which means that the message contained in Batang Hari Sembilan Solo Guitar art itself reminds humans to always thank God for that they have obtained.
With Batang Hari Sembilan Solo Guitar art performance in sedekah bumi activities, people's connection may be maintained and strengthened. This may be observed in the activities before the Batang Hari Sembilan Solo Guitar art ceremony and performance. All people of Batu Urip Hamlet held a discussion and cooperated to build the place where the performance was to be held and also prepared anything to be used in the ceremony together (Interview, Kosim, 2 January 2019).

Merriam (1964) stated that the Communication Function in music applicable in a cultural area contains its own signals that only the culture supporting society knows it. Local song delivering the message contained in the text of the song is a type of communication. Besides, however, the music itself (without text) may communicate something. Music is not a universal language that anyone and everywhere may understand since each type of music is born and growing in a society with its culture.

The communication function in this art also covers where Malay people are used to using pantun as a socialization media, pantun of (belinjangan) love, and so on. According to (Saliyam, interview, 28 December 2018) pantun has been used as a socialization media, for belinjangan since a long time ago.

By expressing through pantun, the atmosphere may be less awkward and easier to get familiar with. Below is an example of pantun belinjangan:

Betang hagu umban di tebang

Betang duku di buat hahang

Jengan ragu jengan bimbang

Linjang ku tuk ngas suhang

We may observe that the third and fourth lines are the content. The meaning of the pantun above is that a person is seducing his idol that his love (linjang) is only for her. Thus, pantun in the Batang Hari Sembilan Solo Guitar art may be taken as Batu Urip hamlet people as a medium of communication and medium of socialization. 
The function of Pantun as communication also exists when the artist advises pantun as the media to society. The meaning of advice expression in the $\mathrm{Ba}$ tang Hari Sembilan Solo Guitar art is in the part of pantun in the content of the Batang Hari Sembilan Solo Guitar art. Below is an example of pantun of advice:

Bukannye senang duduk di tang-

ge

Ciriku duduk jauh pikiran

Jangan Takut membujang tue

Tue diluar mude di dalam

The meaning of pantun above is an expression of advice to young men in Batu Urip hamlet who have not met their partner. Below is an example of pantun of advice:

\section{Ketintang membawe Taji \\ Kemane ncakak sarungnye \\ Selop jepang dikde tebeli \\ Jangan bemance bebini due}

The meaning of pantun above is an advice and also serves the entertainment function to married men. In the third and fourth lines "Selop jepang dikde tebeli, jangan bemance bebini due" means that one is unable to afford flip-flops, do not even think to have two wives.

As stated by Akmal (2015) Pantun is not only appropriate to convey entertaining matters, but it may also deliver serious discourse such as advice. At the highest level, pantun delivers noble values to the society in its own way.

\section{Entertainment Function}

Besides as ritual function and preservation function, Batang Hari Sembilan Solo Guitar art in the sedekah bumi activity in Batu Urip hamlet is also used as an entertainment function for those who participate or only watch it. The other function of Malay pantun is entertainment. The term entertainment here is not one of Islamic teaching. The entertainment here is one to fulfill the human desire of beauty through various dimensions. Human naturally likes beauty. After enjoying the beauty, they will be entertained, and their souls will be filled with enlightenment.

The people who watch Batang Hari Sembilan Solo Guitar art in Sedekah Bumi Activities in Batu Urip hamlet usually want entertainment. Similarly, the audience who only want entertainment, they obtain entertainment after listening to the lyrics of pantun sung.

With the Batang Hari Sembilan Solo Guitar art performance in Hamlet Sedekah Bumi Activities, all people may watch the free entertainment. Such an art performance is infrequently held; thus, it may become entertainment that is greatly longed by the people in Batu Urip hamlet (Interview with Yesi, 25 December 2018).

As stated by Merriam (1964), the Entertainment Function is that in any community in the world, music serves as an entertaining instrument. Music naturally contains entertaining elements, which may be observed from its melody or lyric. Below is an example of a lyric of entertaining pantun.

\section{Bukannye senang duduk di tangge \\ Ciriku duduk jauh pikiran \\ Jangan Takut membujang tue \\ Tue diluar mude di dalam}

In the third and fourth lines, we may observe in the content of pantun that the meaning of the pantun is that an artist says that an old-young man who has not found a partner should not be discouraged, old on the external but young on the inside. With the pantun the audience instantly gets entertained with advice, which also serves as a media of entertainment.

\section{CONCLUSION}

The Batang Hari Sembilan Single Guitar Art is a traditional art that is still developing in Batu Urip Hamlet, Batu Urip Taba Village, East Lubuklinggau I District, Lubuklinggau City, South Sumatra Province. Batang Hari Sembilan is a term for music rhythm with solo guitar strumming developing in South Sumatera region containing pantuns of daily life. 
Pantun is the identity of the people of Batu Urip hamlet since pantun is the original literary work of Malay people and plays a big role in their life since pantun contains life values which are appropriate to Islam, and it is through pantun that tunjuk ajar is distributed, passed down and developed. The functions of pantun in the Batang Hari Sembilan Solo Guitar art performance in the Sedekah Bumi Activities in Batu Urip Hamlet are as the ritual function, emotional expression function, communication function, and entertainment function.

\section{REFERENCES}

Akmal. (2015). Kebudayaan Melayu Riau (Pantun,Syair, Gurindam). Jurnal Risalah, 26(4), 159-165.

Andriani, T. (2012). Pantun Dalam Kehidupan Melayu (Pendekatan historis dan antropologis ). Jurnal Sosial Budaya, 9(2), 195-211.

Burhani, A. N. (2017). Geertz Trichotomy of Abangan, Santri, And Priyai: Controversy and Continuity. Journal of Indonesian Islam, 11(2), 329.

Dja'far, M. F (1994). Budaya Melayu Sumatera Utara dan Enkulturasinya. Yogyakarta: Balai Kajian dan Pengembangan budaya.

Erwina, E. (2011). Pantun dan Fungsinya dalam Kebudayaan Masyarakat Melayu Sumatera Utara. Universitas Suma- tera Utara Medan. Retrieved from http:/ / www.etnomusikologiusu. com/uploads/1/8/0/0/1800340/ winamelaka2011.pdf

Firmansyah, F. (2015). Bentuk dan struktur musik batang hari Sembilan. Ekspresi Seni, 17(1), 1-164.

Geertz, C. (1964). The Religion of Java. Glencoe, Ill: Free Press

Gill, T. G. (2013). Culture, complexity, and informing: How shared beliefs can enhance our search for fitness. International Journal of an Emerging Transdiscipline, 16(1), 71-98.

Merriam, P. A. (1964). The Anthropology of Music. Chicago: Northwestern University Press.

Sayekti. (2009). Sayekti Sastra Melayu Klasik dalam Pengajaran Sastra Indonesia di SMA. Madiun: Universitas Widya Mandala.

Soedarsono. (1995). Pendidikan Seni dalam Kaitannya dengan Kepariwisataan. Paper presented a Seminar in Department of Sendratasik FPBS IKIP Yogyakarta, Februari 12, 1995). Yogyakarta.

Suharto, S., \& Subroto, E. (2014). The Equivalence of Translated Songs Lyrics And Their Effects: The Case Of Translated Ecclesial Songs. Harmonia: Journal of Arts Research and Education, 14(2), 131-139. 